\title{
PREVENTION AND TREATMENT OF CEREBRAL VASOSPASM AFTER ANEURYSMALSUBARACHNOID HEMORRHAGE
}

\author{
Valentina D. Opančina
}

Faculty of Medical Sciences, University of Kragujevac

\section{ПРЕВЕНЦИЈА И ТРЕТМАН ЦЕРЕБРАЛНОГ ВАЗОСПАЗМА НАКОН АНЕУРИЗМАЛНЕ СУБАРАХНОИДАЛНЕ ХЕМОРАГИЈЕ}

\section{Валентина Д. Опанчина}

Факултет медицинских наука, Универзитет у Крагујевцу

Примљен/Received: 18.7.2016.

Прихваћен/Accepted: 29.7.2016.

\section{ABBREVIATIONS:}

SAH - subarachnoid hemorrhage

ASAH - aneurysmal subarachnoid hemorrhage

DCI - delayed cerebral ischemia

CBF - cerebral blood flow

CVS - cerebral vasospasm

DIND-delayed ischemic neurological deficit

CCB -a calcium channel blocker

$\mathrm{Mg}$ - Magnesium

PTA - percutaneous transluminal angioplasty

IA - intra-arterial.

\section{ABSTRACT}

Background. Cerebral vasospasm is the most serious complication of subarachnoid hemorrhage. It can be defined as deferred and selflimited condition whose severity is linked to the volume, solidity, prolonged presence and location of subarachnoid blood. Almost $70 \%$ of these patients have angiographic manifestation of vasospasm, and circa $50 \%$ of these patients experience neurological deficits. The purpose of this article is to concentrate on the currentprogress andprospective approaches in the prevention and treatment of cerebral vasospasm after aneurismal subarachnoid hemorrhage.
Materials and methods. A thorough literature search through the Medline and Ebscodatabases was performed. Original investigations, meta-analyses and reviews from the past 10 years, with accessible full-texts, in the English language, were selected.

Prevention and treatment. The main medical approach for prevention of vasospasm includes upkeep of normal blood circulation level and oral Nimodipine.The only type of treatment for cerebral vasospasm, which is recognized at present, is induced hypertension with the maintenance of euvolemia. Percutaneous transluminal angioplasty and/or selective intra-arterial vasodilator therapy are recommended in patients with symptomatic cerebral vasospasm, especially in those without quick response to hypertensive therapy.

Conclusion. Novel approaches with immunomodulators, anesthetics, hypothermia, acupuncture, neuroprotective agents and multimodal treatment regimens are under active development and hold promise in the treatment of vasospasm in the coming years.

Key words: cerebral vasospasm, subarachnoid hemorrhage, aneurysms, treatment, prevention. 


\section{САЖЕТАК}

Увод. Церебрални вазоспазам је најозбиљнија компликација субарахноидалног крварења. Може се дефинисати као одложено и самоограничавајуће стање чија је тежина повезана са запремином, густином, продуженим присуством и локацијом субарахноидалне крви. Око 70\% ових пацијената показује ангиографске доказе вазоспазма, а око 50\% њих има неуролошке дефиците. Циљ овог чланка је преглед новијег напретка и будуће перспективе у превенцији и лечењу церебралног вазоспазма након анеуризмалног субарахноидалног крварења.

Материјали и методе. Извршено је опсежно претраживање литературе у Medline и Ebsco базама података. Изабрани су оригинални радови, мета-анализе и прегледни чланци из последњих 10 година, са приступачним и доступним текстовима, на енглеском језику.

Превенција и лечење. Главна медицинска стратегија за превенцију вазоспазма обухвата одржавање нормалног волумена циркулишуће крви и оралну терапију нимодипином. Тренутно, једина утврђена терапија за лечење церебралног вазоспазма је еуволемички индукована хипертензија. Перкутана транслуминална ангиопластика и/или селективна интра-артеријска вазодилататорна терапија су разумне код пацијената са симптоматским церебралним вазоспазмом, нарочито код оних који не реагују брзо на хипертензивну терапију.

Закључак. Нови приступи који се активно развијају и пуно обећавају у лечењу вазоспазма у наредним годинама обухватају имуномодулаторе, анестетике, хипотермију, акупунктуру, неуропротективна средства и мултимодалне режиме лечења.

Кључне речи: церебрални вазоспазам, субарахноидално крварење, анеуризме, третман, превенција.

\section{BACKGROUND}

Subarachnoid hemorrhage (SAH) is a lifethreatening condition that can develop spontaneously or as a result of trauma ${ }^{1,2,3}$. Its mortality rate goes from 10 to $20 \%{ }^{2}$.Aneurysmal subarachnoid hemorrhage (ASAH) is a type of spontaneous stroke that affects $80 \%$ of SAH patients, defined as blood release into the subarachnoid space provoked by the aneurysmal rup- ture $^{3,4,5}$.Approximately, one third of ASAH survivors develops delayed cerebral ischemia (DCI) induced by narrowing of cerebral blood vessels and decreased cerebral blood flow $\left(\mathrm{CBF}^{5}{ }^{5,6,7,8}\right.$. A segmental or diffuse narrowing of the lumen of intracranial arteries is also known as cerebral vasospasm $(\mathrm{CVS})^{5,9}$.Ecker and Riemenschneiderhave debuted the concept of CVS after SAH, in $1951^{6}$.

CVS is the most serious complication of SAH and can be defined as deferred and self-limited condition whose severity is linked to the volume, solidity, prolonged presence and location of subarachnoid blood ${ }^{3,6,9}$. Hemoglobin in the subarachnoid blood brings to higher productivity of reactive oxygen species, which provokes secretion of the vasoconstrictor substances and decreases levels of the vasodilators $3,7,10$. SAH induced vasospasm is a complex entity that contains delayed and reversible vasculopathy, damaged auto regulatory function, and hypovolemia ${ }^{11,12,13}$. DCI typically lasts the first 2 weeks after SAH, while CVS reaches maximal narrowing between day 5 and 14, and then gradual resolution over 2 to 4 weeks ${ }^{5,14,15}$. Almost $70 \%$ of ASAH patients haveangiographic manifestation of vasospasm, and circa $50 \%$ of these patients experience predominantlycloudingof consciousness and language impairments ${ }^{3,6,11,15}$. These symptoms are known as delayed ischemic neurological deficit (DIND) or clinical vasospasm ${ }^{3,6}$. Angiographic vasospasm can be illustrated as a narrowing of the contrast medium column in main arteries of the brain $^{15}$. Proximal vessels, situated at the base of the brain, are preferentially affected ${ }^{13}$.In spite of continuous evolvement of endovascular gadgets and techniques, there are still hazards specific to this type of treatment ${ }^{14}$.

This review concentrates on the present insight into theCVStreatment and prevention choices. In the first section, prevention strategies are discussed. In the second section, the topic is medical treatment. In third section interventional treatment and novel approaches are reviewed. Through this, wehope to analyze pending matters regarding the future exploration of CVS after SAH.

\section{MATHERIALS AND METHODS}

A thorough literature search through the Medline and Ebscodatabases was performed, using the following terms: (cerebral vasospasm) AND (aneurysm subarachnoid hemorrhage) AND (treatment or management) AND (prevention) AND 
(review OR animal experimental OR clinical trial).

We selected original investigations, metaanalyses and reviews from the past 10 years, with accessible full-texts, in the English language, as well as significant reference lists of articles which could contribute to the readers' comprehension.

\section{Prevention of cerebral vasospasm after aneurysmal subarachnoid hemorrhage}

Morbidity and mortality caused by CVS, could be reduced by prevention of DIND. The main medical approach for prevention of vasospasm includes upkeep of normal blood circulation level and oral Nimodipine ${ }^{5,6,16}$.

Treatment with oral Nimodipine, a calcium channel blocker (CCB), was accepted in practice in the USA since 1983, when a trial showed more neurological deficit in patients treated with placebo, than in those treated with Nimodipine ( $\mathrm{p}$ $<0.03)^{17}$. Oral Nimodipine lowers the incidence of vasospasm-caused brain ischemia by $34 \%$ and the rate of ASAH poor outcomes by $40 \%^{6}$. Its neuroprotectivefeatures most likely contribute to positive results in $\mathrm{CVS}^{6,14}$. Nimodipinehas a low complication rate, can diminish the risk of secondary DCI and may achieve positive angiographic and clinical results ${ }^{14}$.

Statins are here reviewed as another group of potential vasospasm preventing drugs. Some trials suggested that they boost cerebral vascular reactivity ${ }^{6,14}$.One meta-analysis showed beneficial effects of statins on incidence of delayed vasospasm, ischemic injury, and mortality, while another meta-analysis failed to show such results $^{16}$. Recent meta-analysis showed higher number of complications with statin therapies than their favorable outcomes ${ }^{17}$. Magnesium $(\mathrm{Mg})$ has also been studied because of its inhibitory function of vascular smooth muscle contraction $^{7}$. It is recommended to monitor $\mathrm{Mg}$ levels and supplement it to normal, even though it is shown that $\mathrm{Mg}$ doesn't have better performance than placebo in reducing SAH vasospasm ${ }^{17}$.The most encouraging novel drugs for vasospasm prevention are endothelin receptor antagonists, due to the endothelin I-caused vasoconstriction $^{7,16}$. Nonetheless, clinical trials were not able to show significant beneficial effect of the endothelin receptor antagonists and large number of complications were presented ${ }^{16,17}$.

\section{Medical Therapy in SAH-Induced} Cerebral Vasospasm

The main goal of therapeutic strategies in ASAH are treatment of CVS, prevention of DCIand enhancement of clinical outcomes ${ }^{6,16}$. The ultimate intention of CVStreatment after $\mathrm{SAH}$ is dodging the development of DIND ${ }^{17}$. The only type of treatment for CVS after SAH, which is recognized at present, is induced hypertension with the maintenance of euvolemia 5 . Other therapies that were studied did not show adequate performance in human studies ${ }^{5,9}$.

Triple-H therapy (hypertension, hypervolemia, and hemodilution) was widely used for prophylaxis and treatment of $\mathrm{CVS}^{6}$. Hypervolemia and hemodilution are not beneficial forCBF and are not recommended nowadays ${ }^{16}$. Induced hypertension is the only approved element of triple- $\mathrm{H}$ therapy ${ }^{5}$. Hyperdynamic therapy by increasing blood pressure, boostsCBF and oxygenation of cerebral tissue, which helps with the reversal of vasospasm-induced neurological 5,16 . It is considered the best available medical option for treatment of cerebral vasospasm ${ }^{16}$, ${ }^{18}$.Furthermore, various case series confirm these beneficial results of inotropic agents in patients who do not react on vasopressor therapy ${ }^{5,18}$.

As established vasospasm prophylaxis, $\mathrm{CCB}$ were investigated for their potential role in treatment ${ }^{19}$. Nimodipine, an L-type CCB, is currently the only pharmacologic agent showing an improvement in neurological outcomes when used for a period of 21 days, every $4 \mathrm{~h}$ after aneurysmal rupture, suggested by the current guidelines of the American Stroke Association ${ }^{14}$, ${ }^{16}$.Intravenous nicardipinedidn't show effect on outcomes after three months of use and verapamil is not selective to cerebral vasculature and its use requires more research ${ }^{5,14}$.

Antioxidants, such as methylprednisolone, tirilazadmesylate andastaxanthin, may prevent oxidative stress and reduce incidence of $\mathrm{DCI}^{5,16}$. Efficacy of astaxanthinin experimental animals with SAH was investigated. It showed reduction of brain edema, neural cells apoptosis, and neurological dysfunction. No side effects were reported following astaxanthin use and it may represent a new promising therapeutic option ${ }^{16}$.

In order to obtain direct effect on early brain injury, vasodilators should be introduced immediately after admission tohospita ${ }^{16}$.Betaestradiol, a potent vasodilator, was tested, but showed large number of adverse effects ${ }^{13,20}$. Nitric oxide donors, such as: sodium nitrate, sodium 
nitroprusside, and nitrite, were investigated in experimental studies ${ }^{16}$. Results showed that they prevent CVS ina primatemodel, but they are not useful clinically due to their short half-life and its potential toxicity ${ }^{5,16}$. Nonsteroidal anti-inflammatory drugs may reduce inflammatory response and decrease the odds for poor outcomes, but they are not used in practice due to mixed results ${ }^{16}$.Clinical studies with antiplatelet agents and inhibitors of thrombus formation showed contrasting outcomes: one study showed reduced risk of cerebral infarction in patients using aspirin and another study showed increased hemorrhagic volume in patients habitually using cyclooxygenase inhibitors ${ }^{16,19}$. Experimental models showed improvement of neurological performanceafter limitation of neuronal inflammation ${ }^{16}$.

\section{Interventional treatment}

Recent recommendations from the American Stroke Association recommend the use of percutaneous transluminal angioplasty (PTA) and/or selective intra-arterial vasodilator therapy in patients with symptomatic CVS, especially in those without quick response to hypertensive therapy ${ }^{5}$, $13,17,21$

PTA for the treatment of CVS was first described in $1984 .{ }^{17}$ Later publications showed that PTA reverses angiographic spasm of large proximal CVS, augments CBF, and may reverse neurological deficits ${ }^{5,13}$. Angioplasty with intraarterial (IA) administration of papaverine may show better efficacy when distal vessels are affected with CVS ${ }^{9}$.Some investigators have suggested that IA papaverine has influence on paradoxical vasospasm, increased intracranial pressure and has neurotoxic effects, which limited its clinical utility ${ }^{9,19,22}$. Several case series have shown better safety results of other IA vasodilators, including: verapamil, nicardipine, nimodipine, and milrinone, than papaverine, but that was not supported by adequate trials 5, ${ }^{17}$.Several retrospective studies with propose neurological progress after one dose of IA verapamil 17. There are evidences that indicate reduction of angiographic evidence of spasm after treatment with IA nicardipine bolus ${ }^{19,21}$. IA Dantrolene might be valuable in serious cases and was also used intravenously for treatment of refractory vasospasm ${ }^{1922}$.A small case series of patients who were treated with continuous IAnimodipine for 1-5 days had improvement in angiographic vasospasm, and 13 of them gave the impression of good respond to treatment ${ }^{19}$.
Intraluminal balloon angioplasty has best treatment reportsfor refractory vasospasm due to the enhancement in vessel diameter and clinical improvement after treatment ${ }^{19,22}$.This intervention is often used in patients that don't show improvementafterhyperdynamic therapy ${ }^{9,21}$. It is performed by a catheter that introduces a balloon, which is inflated inside the lumen of the affected vessel ${ }^{19}$.In general, balloon angioplasty can be used for accessible lesions and accompanies infusion of vasodilators such as CCB and phosphodiesterase inhibitor (milrinone) for more distal vessels ${ }^{9}$.

Transient aortic obstruction is described as novel approach for CVS treatment ${ }^{22}$. It is executedwitha balloon catheter, inserted into the femoral artery and inflated about and below the renal arteries, for the sake of occlusion of the abdominal aorta lumen to $70 \%$ of its diameter ${ }^{17,19}$. It has been shown that this approach improvesCBF in experimental ischemic stroke patients $^{19}$.

\section{CONCLUSION}

Vasospasm after ASAHstill presents a demanding issue ${ }^{6,23}$. The only type of treatment for cerebral vasospasm after $\mathrm{SAH}$, which is recognized at present, is induced hypertension with the maintenance of euvolemia ${ }^{5}$. Despite the accepted practice of Nimodipine and its positive outcomes it is not possible to use it per $\mathrm{se}^{16}$. Balloon angioplasty and intra-arterial vasodilator therapy are common in practice, but their outcomes are still ambiguous9. Novel approaches with immunomodulators, anesthetics, hypothermia, acupuncture, neuroprotective agents and multimodal treatment regimens are under active development and hold promise in the treatment of vasospasm in the coming years ${ }^{13,19}$.

\section{ACKNOWLEDGMENT}

The author is grateful to prof. Slobodan M. Jankovic, MD, DSc, MSc, Prim., for his valuable and detailed suggestions that improved this paper and made possible its finalization.

\section{REFERENCES}

1. Hirano K, Hirano M. Current perspective on the role of the thrombin receptor in cerebral vasospasm after subarachnoid hemorrhage. J. Pharmacol. Sci. 2010; 114(2): 127-33.

2. Muñoz-Guillén NM, León-López R, Túnez-Fiñana I, Cano-Sánchez A. From vasospasm to early brain injury: New frontiers in subarachnoid haemorrhage research. Neurologia 2013; 28(5): 309-16. 
3. Cho SY, Lee DH, Shin HS, Lee SH, Koh JS, Jung WS, et al. . The efficacy and safety of acupuncture for cerebral vasospasm after subarachnoid hemorrhage: Study protocol for a randomized controlled trial. Trials 2015; 16 (68).

4. Sehba FA, Pluta RM, Zhang JH. Metamorphosis of subarachnoid hemorrhage research: From delayed vasospasm to early brain injury. Mol. Neurobiol. 2011;43(1): 27-40.

5. Athar MK, Levine JM. Treatment options for cerebral vasospasm in aneurysmal subarachnoid hemorrhage. Neurotherapeutics 2012; 9(1): 37-43.

6. Dabus G, Nogueira RG. Current options for the management of aneurysmal subarachnoid hemorrhageinduced cerebral vasospasm: A comprehensive review of the literature. IntervNeurol 2013; 2(1): 30-51.

7. Rowland MJ, Hadjipavlou G, Kelly M, Westbrook J, Pattinson KTS. Delayed cerebral ischaemia after subarachnoid haemorrhage: Looking beyond vasospasm. Br J Anaesth 2012;109(3): 315-29.

8. Etminan N, Vergouwen MDI, Ilodigwe D, Macdonald RL. Effect of pharmaceutical treatment on vasospasm, delayed cerebral ischemia, and clinical outcome in patients with aneurysmal subarachnoid hemorrhage: A systematic review and meta-analysis. Journal of cerebral blood flow and metabolism 2011;31(6): 144351 .

9. Lin BF, Kuo CY, Wu ZF. Review of aneurysmal subarachnoid hemorrhage: Focus on treatment, anesthesia, cerebral vasospasm prophylaxis, and therapy. ActaanaesthesiologicaTaiwanica 2014; 52(2): 77-84.

10. Naraoka M, Matsuda N, Shimamura N, Asano K, Ohkuma $\mathrm{H}$. The role of arterioles and the microcirculation in the development of vasospasm after aneurysmal SAH. Biomed Res Int. 2014

11. Rodríguez-García PL, Rodríguez-Pupo LR, RodríguezGarcía D. Diagnosis of delayed cerebral ischaemia and cerebral vasospasm in subarachnoid haemorrhage. Neurologia 2010; 25(5): 322-30.

12. Miller BA, Turan N, Chau M, Pradilla G. Inflammation, vasospasm, and brain injury after subarachnoid hemorrhage. Biomed Res Int. 2014
13. Keyrouz SG, Diringer MN. Clinical review: Prevention and therapy of vasospasm in subarachnoid hemorrhage. Crit Care. 2007; 11(4): 220.

14. Liu Y, Qiu H, Su J, Jiang W. Drug treatment of cerebral vasospasm after subarachnoid hemorrhage following aneurysms. Chinese Neurosurgical Journal 2016; 2(4)

15. Priebe HJ. Aneurysmal subarachnoid haemorrhage and the anaesthetist. Br J Anaesth 2007; 99(1): 102-18.

16. Cossu G, Messerer M, Oddo M, Daniel RT. To look beyond vasospasm in aneurysmal subarachnoid haemorrhage. Biomed Res Int. 2014

17. Bauer AM, Rasmussen PA. Treatment of intracranial vasospasm following subarachnoid hemorrhage. Front Neurol 2014; 5 (72).

18. Adamczyk P, He S, Amar AP, Mack WJ. Medical Management of Cerebral Vasospasm following Aneurysmal Subarachnoid Hemorrhage: A Review of Current and Emerging Therapeutic Interventions. Neurol Res Int. 2013

19. Durrant JC, Hinson HE. Rescue therapy for refractory vasospasm after subarachnoid hemorrhage. CurrNeurolNeurosci Rep. 2015; 15(2): 521.

20. Ding D, Starke RM, Dumont AS, Owens GK, Hasan DM, Chalouhi N, Lin CL. Therapeutic implications of estrogen for cerebral vasospasm and delayed cerebral ischemia induced by aneurysmal subarachnoid hemorrhage. Biomed Res Int. 2014

21. Steiner T, Juvela S, Unterberg A, Jung C, Forsting M, Rinkel G, -European Stroke Organization . European Stroke Organization guidelines for the management of intracranial aneurysms and subarachnoid haemorrhage. Cerebrovasc Dis. 2013; 35(2): 93-112.

22. Diringer MN. Management of aneurysmal subarachnoid hemorrhage. Crit Care Med. 2009;37(2): 432-40.

23. Caner B, Hou J, Altay O, Fujii M, Zhang JH. Transition of research focus from vasospasm to early brain injury after subarachnoid hemorrhage. J Neurochem 2012; 123(2): 12-21. 